\title{
Stanowisko Polskiego Towarzystwa Dermatologicznego w sprawie wykonywania zabiegów z zakresu medycyny estetycznej oraz diagnostyki i leczenia chorób dermatologicznych przez osoby nieposiadające wykształcenia lekarskiego
}

Dermatol Rev/Przegl Dermatol 2017, 104, 579-582

W związku z nasilającym się w ostatnich latach zjawiskiem wykonywania w Polsce zabiegów lekarskich z zakresu dermatologii estetycznej i szeroko rozumianej medycyny estetycznej przez osoby bez wykształcenia lekarskiego widzimy pilną konieczność wprowadzenia nowych uregulowań prawnych w celu ochrony osób poddających się takim zabiegom przed ryzykiem utraty zdrowia i życia w konsekwencji nieumiejętnego wykonywania zabiegów przez osoby bez odpowiednich uprawnień.

Żadne krótkie szkolenie, nawet zakończone otrzymaniem „certyfikatu”, nie zastępuje wiedzy i umiejętności zdobytych przez 6 lat studiów lekarskich i - w przypadku specjalistów dermatologów-wenerologów - przez dodatkowe 5 lat szkolenia specjalizacyjnego. Jedynym legalnym dokumentem upoważniającym do udzielania świadczeń lekarskich jest prawo wykonywania zawodu lekarza. Inne "certyfikaty" potwierdzające nabycie umiejętności wykonywania zabiegowych procedur dermatologii estetycznej, uzyskane przez osoby niebędące lekarzami, nie są legalne w świetle obowiązujących przepisów prawa.

Należy przypomnieć, że wykonywanie zabiegów z zakresu dermatologii i medycyny estetycznej z użyciem głębokich peelingów, mezoterapii igłowej, stosowanie wypełniaczy, toksyny botulinowej, osocza bogatopłytkowego, nici liftingujących, krioterapii, elektroterapii i laseroterapii (z wyjątkiem laserów biostymulujących i niskoenergetycznych) to świadczenia medyczne (zabiegi lekarskie), a nie kosmetyczne.

Zabiegi, o których mowa wyżej, nie mogą być zakwalifikowane jako zabiegi kosmetyczne z wielu powodów. Po pierwsze, stosowane przy ich wykonywaniu preparaty są lekami lub wyrobami medycznymi w rozumieniu przepisów ustawy z dnia 6 września 2001 r. Prawo farmaceutyczne (Dz.U.2016.2142 t.j. z dnia 23.12.2016 r.) i ustawy z dnia 20 maja 2010 r. o wyrobach medycznych (Dz.U. 2017.211. t.j. z dnia 3.02.2017 r.). Zasady pobierania krwi i jej składników (osocze bogatopłytkowe) regulują natomiast przepisy ustawy z dnia 22 sierpnia 1997 r. o publicznej służbie krwi (Dz.U.2014.332. t.j. z dnia 10.03.2014 r.). Z przepisów tej ostatniej ustawy wynika, że ustawodawca nie przewidział możliwości pobierania krwi w celu wykorzystania w zabiegach kosmetycznych, a wyłącznie w celach medycznych.

Ustawodawca traktuje również toksynę botulinową jako lek wydawany z przepisu lekarza na receptę, tak więc jego podanie ma charakter świadczenia medycznego. Osoba niebędąca lekarzem nie może legalnie wejść w posiadanie toksyny botulinowej. Z powyższego wynika, że jeżeli ten produkt leczniczy jest stosowany do wykonywania zabiegów przez osoby inne niż lekarze, to dzieje się to $\mathrm{z}$ naruszeniem obowiązujących przepisów prawa. Również niezgodne z prawem jest odsprzedawanie i oddawanie osobie innej niż lekarz toksyny botulinowej.

Preparaty kwasu hialuronowego i inne substancje z grupy tzw. wypełniaczy są wstrzykiwanymi implantami służącymi do przywracania objętości tkanek. Zgodnie z rozporządzeniem Ministra Zdrowia $\mathrm{z}$ dnia 5 listopada 2010 r. w sprawie klasyfikowania wyrobów medycznych (Dz.U.2010.215.1416 z dnia 16.11.2010 r.) należą one do klasy III pod względem ryzyka stosowania. Do klasy tej zalicza się inwazyjne wyroby medyczne, w tym chirurgiczne inwazyjne wyroby medyczne przeznaczone do chwilowego oraz do krótkotrwałego użytku, takie jak implanty tkankowe. Zgodnie z art. 2 ust. 1 pkt 38 ustawy o wyrobach medycznych wyrób medyczny to narzędzie, przyrząd, urządzenie, oprogramowanie, materiał lub inny artykuł stosowany samodzielnie lub w połączeniu, w tym z oprogramowaniem przeznaczonym przez jego wytwórce do używania specjalnie w celach diagnostycznych lub terapeutycznych i niezbędnym do jego właściwego stosowania, przeznaczony przez wytwórcę do stosowania u ludzi w celach medycznych. Zgodnie z art. 90 ust. 1 tej ustawy wyrób powinien być właściwie dostarczony, prawidłowo zainstalowany i utrzymywany oraz używany zgodnie z przewidzianym zasto- 
sowaniem, a użytkownik wyrobu jest zobowiązany do przestrzegania instrukcji jego stosowania. Zapisy wymienionej wyżej ustawy nadal (pomimo licznych interwencji różnych grup lekarskich) wprost nie wymagają posiadania odpowiednich kwalifikacji do stosowania określonych wyrobów medycznych. Niemniej takie wymaganie jest określone w instrukcji stosowania wyrobu medycznego. Instrukcja dostarczana z wyrobem zawiera ograniczenia co do kręgu osób, które mogą stosować dany wyrób. Jest to uzasadnione działaniem, sposobem użycia i ryzykiem związanym z jego stosowaniem i powinno być rygorystycznie przestrzegane przez użytkowników wyrobów medycznych. Zgodnie z zaleceniami producenta zgłoszonymi do Urzędu Rejestracji Produktów Leczniczych, Wyrobów Medycznych oraz Produktów Biobójczych, z wymaganiami przewidzianymi ustawą o wyrobach medycznych oraz instrukcją użytkowania zamieszczonymi na ulotce dołączonej do opakowania wyroby te (implanty tkankowe) mogą być stosowane wyłącznie przez lekarzy, którzy przeszli odpowiednie przeszkolenie.

Wymagania te podyktowane są koniecznością posiadania wiedzy, która ma zasadnicze znaczenie dla bezpieczeństwa zabiegu. Użycie implantów tkankowych może prowadzić do natychmiastowych i odległych poważnych działań niepożądanych, takich jak martwica tkanek, stany zapalne, ropnie, trwała utrata wzroku, reakcja anafilaktyczna i inne, włącznie z ryzykiem zgonu.

Wszelkie tego typu zabiegi powinny być wykonywane zgodnie $z$ przepisami sanitarno-epidemiologicznymi, czyli w gabinetach lekarskich zabiegowych, które spełniają odpowiednie wymogi wskazane w ustawie z dnia 15 kwietnia 2010 r. o działalności leczniczej (Dz.U.2016.1638. t.j. z dnia 7.10.2017 r.) oraz wydanych na jej podstawie przepisach wykonawczych. Dodatkowo wykonywanie zabiegów medycznych wiąże się z utylizacją odpadów medycznych i podlega regulacjom zawartym w rozporządzeniu Ministra Zdrowia z dnia 21 października 2016 r. w sprawie wymagań i sposobów unieszkodliwiania odpadów medycznych i weterynaryjnych (Dz.U. z 2016 r. poz. 1819 z dnia 8.11.2016 r.). Brak właściwego wyposażenia oraz niestosowanie się do odpowiednich standardów zwiększa ryzyko infekcji osób trzecich wirusami, takimi jak HCV i HIV.

\section{WYKONYWANIE INWAZYJNYCH ZABIEGÓW LEKARSKICH Z UŻYCIEM URZĄDZEŃ MEDYCZNYCH (NP. LASERÓW) PRZEZ OSOBĘ NIEBĘDĄCA LEKARZEM}

Wykonywanie inwazyjnych zabiegów lekarskich przez osoby niebędące lekarzami jest niezgodne z obowiązującym w Polsce prawem. Procedury ta- kie zastrzeżone są dla lekarzy. W przepisach regulujących udzielanie świadczeń zdrowotnych nie wymieniono kosmetologów i kosmetyczek. Kosmetyczka i kosmetolog, pielęgniarka, położna, fizjoterapeuta i inne osoby nie są zawodowo przygotowani do diagnozowania i usuwania zmian skórnych. Nie mają wiedzy pozwalającej odróżnić te zmiany w celu zastosowania odpowiedniego leczenia. Osoby niebędące lekarzami nie są uprawnione do oceny, które zmiany powinny podlegać leczeniu, a które stanowią tylko defekt estetyczny. Nie są również uprawnione do podejmowania jakichkolwiek prób usuwania zmian skórnych. Nie mają wiedzy dermoskopowej, histopatologicznej oraz umiejętności identyfikowania stanów przednowotworowych i nowotworowych skóry oraz ich różnicowania. Leczenie i usuwanie zmian skórnych przez osoby niebędące lekarzami wiąże się z dużym ryzykiem opóźnienia rozpoznania nowotworu złośliwego skóry i poważnych konsekwencji dla zdrowia i życia osoby, u której wykonywany jest taki zabieg.

\section{DIAGNOZOWANIE I LECZENIE CHORÓB PRZEBIEGAJACCYCH Z ŁYSIENIEM}

Odrębny problem stanowi rosnący w Polsce rynek nieprofesjonalnych usług w zakresie diagnozowania i leczenia chorób przebiegających z łysieniem. Należy podkreślić, że łysienie może być objawem wielu chorób, w tym zaburzeń endokrynologicznych, chorób nowotworowych, ciężkiej niedokrwistości lub chorób autoimmunizacyjnych. W związku z powyższym trichologia i trichoskopia należą do zakresu wysokospecjalistycznej wiedzy dermatologicznej. Z ogromnym niepokojem obserwujemy, że w Polsce usługi tzw. trichologiczne (czyli polegające na diagnozowaniu i leczeniu chorób przebiegających z łysieniem) świadczone są przez osoby bez wykształcenia lekarskiego. Takie zjawisko niesie ze sobą ogromne zagrożenie zdrowia i życia w związku z opóźnieniem w rozpoznaniu poważnych chorób, których łysienie jest pierwszą manifestacją kliniczną.

Należy podkreślić, że ustawa z dnia 5 grudnia 1996 r. o zawodzie lekarza (Dz.U. 1997 Nr 28 poz. 152 z późn. zm.) stanowi, że to lekarze są uprawnieni do diagnozowania i leczenia chorób. Prowadzenie diagnostyki i leczenia „chorób włosów” przez osoby niebędące lekarzami nie jest więc legalne w świetle obowiązujących przepisów ustawowych.

\section{KOMPETENCJE KOSMETYCZKI ORAZ KOSMETOLOGA I I II}

Należy zaznaczyć, że kosmetolog zarówno po studiach $\mathrm{I}^{\circ}$, jak i uzupełniających $\mathrm{II}^{\circ}$ nie ma uprawnień 
do wykonywania wkłuć oraz innych zabiegów naruszających granicę skórno-naskórkową, w tym zabiegów laserowych i elektrokoagulacji. Absolwenci studiów kierunku kosmetologia mają zakres umiejętności zgodny ze standardami kształcenia dla tego kierunku określonymi w załączniku nr 58 do rozporządzenia Ministra Nauki i Szkolnictwa Wyższego z dnia 12 lipca 2007 r. w sprawie standardów kształcenia dla poszczególnych kierunków oraz poziomów kształcenia, a także trybu tworzenia i warunków, jakie musi spełniać uczelnia, by prowadzić studia międzykierunkowe oraz makrokierunki (Dz.U.164.1166 z dnia 13.09.2007 r.). Zapisy powyższego rozporządzenia określają, jakie absolwent studiów tego kierunku powinien posiadać umiejętności, i nie obejmują zabiegów medycznych z zakresu dermatologii estetycznej.

\section{PODSUMOWANIE}

Z niepokojem obserwujemy wzrastającą liczbę zabiegów medycyny estetycznej oraz czynności z zakresu rozpoznawania i leczenia chorób wykonywanych przez osoby nieposiadające wykształcenia lekarskiego. Zarząd Główny Polskiego Towarzystwa Dermatologicznego, w imieniu wszystkich członków, zdecydowanie się temu przeciwstawia. Uważamy, że naszym obowiązkiem jest poinformowanie o zagrożeniach zdrowotnych dla potencjalnych pacjentów.
Widzimy pilną potrzebę wprowadzenia jednoznacznych przepisów regulujących kwestie omówione w tym piśmie, $w$ tym w szczególności:

a) doprecyzowania, że czynności z zakresu rozpoznawania chorób i leczenia oraz wykonywania zabiegów lekarskich są czynnościami wykonywanymi wyłącznie przez osoby posiadające prawo wykonywania zawodu lekarza,

b) określenia, że zabiegi medycyny estetycznej, $\mathrm{w}$ tym zabiegi inwazyjne wykonywane przy użyciu urządzeń medycznych oraz zabiegi z wykorzystaniem substancji wydawanych na podstawie przepisu lekarza, mogą być wykonywane wyłącznie przez osoby posiadające prawo wykonywania zawodu lekarza,

c) doprecyzowania, że rozpoznawanie chorób, leczenie oraz wykonywanie zabiegów inwazyjnych może być wykonywane jedynie w gabinetach lekarskich spełniających obowiązujące przepisy sanitarno-epidemiologiczne,

d) wprowadzenia zakazu używania nazw zawodowych mogących wskazywać na wiedzę medyczną przez osoby nieposiadające wykształcenia lekarskiego lub odpowiedniego specjalistycznego (,tricholog", ,tzw. lekarz", ,"specjalista medycyny estetycznej", "podolog" itp.),

e) wprowadzenia zakazu reklamy świadczeń lekarskich udzielanych z naruszeniem przepisów prawa.

Zarząd Główny Polskiego Towarzystwa Dermatologicznego prof. dr hab. n. med. Lidia Rudnicka (prezes) prof. nadzw. dr hab. n. med. Barbara Zegarska (członek Prezydium i koordynator Zespołu ds. Dermatologii Estetycznej PTD) prof. dr hab. n. med. Waldemar Placek (wiceprezes) prof. dr hab. n. med. Anna Wojas-Pelc (wiceprezes) prof. dr hab. n. med. Zygmunt Adamski (skarbnik) prof. dr hab. n. med. Adam Reich (sekretarz)

prof. dr hab. n. med. Ligia Brzezińska-Wcisło (członek Prezydium) prof. dr hab. n. med. Roman Nowicki (członek Prezydium)

prof. dr hab. n. med. Grażyna Chodorowska (członek Zarządu Głównego) prof. nadzw. dr hab. n. med. Rafał Czajkowski (członek Zarządu Głównego) prof. dr hab. n. med. Magdalena Czarnecka-Operacz (członek Zarządu Głównego) dr n. med. Joanna Czuwara (członek Zarządu Głównego)

prof. dr hab. n. med. Iwona Flisiak (członek Zarządu Głównego) dr n. med. Monika Kapińska-Mrowiecka (członek Zarządu Głównego) prof. dr hab. n. med. Andrzej Kaszuba (członek Zarządu Głównego) prof. dr hab. n. med. Cezary Kowalewski (członek Zarządu Głównego) prof. dr hab. n. med. Dorota Krasowska (członek Zarządu Głównego) prof. nadzw. dr hab. n. med. Aleksandra Lesiak (członek Zarządu Głównego) prof. dr hab. n. med. Joanna Maj (członek Zarządu Głównego) prof. dr hab. n. med. Sławomir Majewski (członek Zarządu Głównego) prof. dr hab. n. med. Romuald Maleszka (członek Zarządu Głównego) prof. dr hab. n. med. Joanna Narbutt (członek Zarządu Głównego) 
prof. nadzw. dr hab. n. med. Witold Owczarek (członek Zarządu Głównego) prof. nadzw. dr hab. n. med. Małgorzata Sokołowska-Wojdyło (członek Zarządu Głównego) prof. dr hab. n. med. Jacek Szepietowski (honorowy prezes, członek Zarządu Głównego) prof. dr hab. n. med. Anna Woźniacka (członek Zarządu Głównego)

oraz członkowie Zespołu ds. Dermatologii Estetycznej Polskiego Towarzystwa Dermatologicznego lek. Marcin Ambroziak dr n. med. Ewa Chlebus dr n. med. Barbara Pytrus

lek. Małgorzata Suszko dr n. med. Grażyna Wąsik 